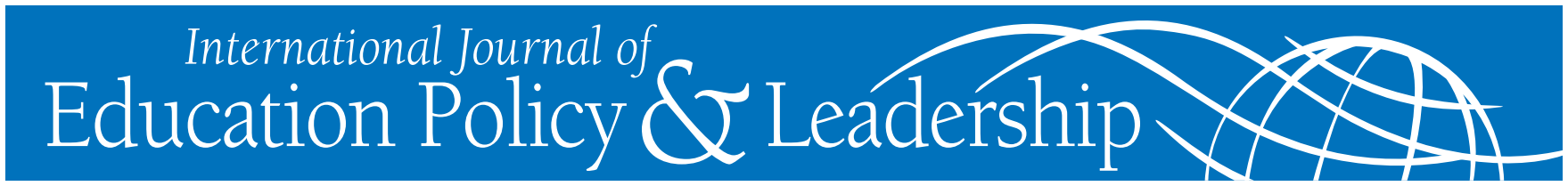

\title{
TEACHERS, POLICYMAKERS AND PROJECT LEARNING: THE QUESTIONABLE USE OF "HARD” AND "SOFT" POLICY INSTRUMENTS TO INFLUENCE THE IMPLEMENTATION OF CURRICULUM REFORM IN HONG KONG
}

\author{
PING KWAN FOK \\ The Chinese University of Hong Kong ${ }^{1}$ \\ KERRY J KENNEDY \\ The Hong Kong Institute of Education \\ JACQUELINE Kin SANG CHAN \\ The Hong Kong Institute of Education
}

\begin{abstract}
Following the return of Hong Kong to Chinese sovereignty in 1997, the government of the Hong Kong Special Administrative Region developed wide-ranging curriculum reforms, including project learning. A recent survey has indicated that more than 80 percent of Hong Kong's primary and secondary schools have adopted project learning as a curriculum task. Such an outcome is hard to reconcile both with the culture of Hong Kong schools and the generally bleak picture that pervades the literature on educational change. In seeking an explanation for this apparent success we focus attention on the policy instruments used by government agencies to facilitate the process of implementation. The paper is located in a theoretical framework with its origins in recent policy theory that to date has not been applied to educational contexts. Our analysis revealed that teachers were caught in a pincer movement that involved voluntary activities promoting project learning and coercive measures that monitored and evaluated successful implementation. Teachers' views of these policy instruments differed markedly from those of policymakers. This confluence of mixed approaches, while apparently successful, is also shown to be problematic.
\end{abstract}

Fok, P. K., Kennedy, K. J., \& Chan, J. K. S. (2010). Teachers, policymakers and project learning: The questionable use of 'hard' and 'soft' policy instruments to influence the implementation of curriculum reform in Hong Kong. International Journal of Education Policy and Leadership 5(6). Retrieved from www.ijepl.org.

After Hong Kong returned to Chinese sovereignty in 1997, the new government of the Hong Kong Special Administrative Region (HKSAR) developed wideranging curriculum reforms. These included project learning as one of the four key tasks of the reform agenda. Project learning is used in the current curriculum reform as a powerful learning strategy that can be developed within and across different learning areas to promote more independent learning capabilities. A recent survey indicated that more than 80 percent of
Hong Kong's primary and secondary schools have reported adopting project learning as a curriculum task (Education and Manpower Bureau (EMB), 2004). This outcome may indicate that teachers have responded positively to the challenges posed by at least one aspect of the government's reform agenda. In an important sense, however, such an outcome runs counter to what much of the educational change literature would have us believe about the adoption and implementation of reform agendas. How can we account for the 
success of project learning in so many Hong Kong schools?

Unlike much of the educational change literature, this paper is not going to focus on the quality of school leadership, the skills of teachers, or other individual factors in schools as an explanation for the reported success of project learning. Rather, the paper will focus on the policy instruments that education decision makers in Hong Kong used to support the educational reform agenda. The paper will draw on data from existing studies and the views of scholars in the field in order to provide a critical assessment of the implementation of project learning. In particular, the concepts of "soft" and "hard" policy instruments will be introduced as a means of analyzing this implementation process. While we will focus on project learning in particular, we believe that the analysis is likely to be applicable to the reform agenda as a whole. The broad theoretical framework for the study will be outlined in the following section.

\section{Theoretical Framework}

Conceptions of "soft" and "hard" policy represent a new approach to understanding policy implementation. The approach has been used particularly in seeking to understand how policy implementation works in multilevel systems where there are few, if any, compliance mechanisms at different levels of the system (Abbott et al., 2000; Torenvlied et al., 2004). "Hard" policy is explicitly embedded in legislation, institutional objectives and commitments, and budgetary allocations. "Soft" policy denotes forms of codes, guidelines, and conventions which, though not binding in nature, exercise authority through persuasion, benchmarking, and the setting of best practices rather than the law (Cini, 2001). The respective merits and limitations of hard and soft means for policy coordination have been noted (Begg, 2004, p. 10). Furthermore, the importance of optimizing between these approaches has been highlighted in implementation (Begg, 2004, p.8). In recent times, examples in the European Union have shown that both "hard" policy and "soft" policy coordination complement formal rules (Begg, Hodson, \& Maher, 2003).

The concepts of "hard" and "soft" policy are used to construct a framework for modes of coordination. While "hard" policy coordination is mainly rule-based, "soft" policy coordination can be subdivided into guided mode and loose mode of coordination (Begg, 2003). Ahonen (2001, p. 2) has argued that there has been no systematic analysis of "soft" methods and uses a typology of "stronger", "intermediate" and "weaker" to classify them. This typology has been adapted to analyze aspects of Hong Kong's curriculum reforms as a case of using "soft" and "hard" policy (Kennedy, Chan, \& Fok, 2006). In this sense, "hard" and "soft" policy are used as conceptual tools to try and better understand curriculum policy implementation in Hong Kong's current educational reform agenda.

In particular, this article will focus on "soft" and "hard" policy instruments that have been used in Hong Kong to support the implementation of project learning. In simple terms, a policy instrument is the instrument or tool that policy implementers use to put policies into effect (Hannaway \& Woodroffe, 2003; Howlett \& Ramesh, 1995; Stone, 1997). Policy instruments have been categorized in different ways. McDonnell \& Elmore (1987) used a four-fold classification of instruments: mandates, inducements, capacity building, and system changing. Chrispeels (1997, pp.475-478) provided a framework to analyze implemented policies with five dimensions as mandates, inducements, capacity-building policies, hortatory or symbolic policy, and system-changing policies. Stewart (1993, pp.323-327) analyzed the functions of policy instruments and identified instruments that provided authority, incentives, or capacity; influence perceptions and values; or promote learning. These categorizations of policy instruments use similar ways to categorize processes that can influence implementation, the most common being mandates, inducement, and capacity.

Howlett \& Ramesh (1995) identified a turning point in the classification of policy instruments in the work of Doern \& Phidd (1992) who categorized instruments by the amount of "legitimate coercion" they involved. "Self-regulation" was seen to be the least coercive and "public ownership" the most coercive. Following this line of thought, Howlett $\&$ Ramesh placed instruments in a spectrum based on the level of teacher involvement (1995, p. 82). Voluntary instruments were at the low end of involvement and compulsory instruments were at the high end. Hannaway and Woodroffe (2003), in a different way, broadly divided policy instruments in the educational field into market-based policy instruments and accountability 
and incentive-based instruments. This division separated two types of instruments, but without seeing them on a spectrum.

Building on previous work relating to policy instruments, this paper classifies them as "soft" and "hard". "Soft" policy instruments are nonbinding policy recommendations, guidelines, informational devices, or binding agreements (Torenvlied et al., 2004). Using "soft" policy instrument as a concept for understanding evolving forms of regulation within the social policy is not new (Ritchie, 2003). In respect to curriculum, "soft" policy instruments include the broad policy guidelines, professional development opportunities, school evaluations and performance indicators ${ }^{2}$, and other voluntary agreements (those without legally binding commitments and other enforcement procedures). Adapted from international law and European Union policy analysis (Hertin at al,, 2003; KoulaimahGabriel et al., 1997; Torenvlied et al., 2004), "soft" and "hard" policy instruments are different in nature and substance. "Soft" policy instruments have no enforcement mechanisms and allow maximum space for implementers, while "hard" policy instruments are enforced through the legal system and are only subject to legal interpretation. This comparison highlights the importance of understanding the characteristics of the policy instruments being used in implementing curriculum reform. Table 1 summarizes the differences between hard and soft policy instruments.

\section{Project learning as part of Hong Kong's educational reforms}

Project learning, moral and civic education, reading to learn, and information technology for interactive learning are the four key tasks advocated in the wideranging "learning to learn" educational reforms (Curriculum Development Council (CDC), 2001, p.83). The use of project learning in schools aims to help students to develop independent learning capabilities through and across Key Learning Areas (KLAs). It is recommended to schools as part of the curriculum reform because schools and teachers can easily make good use of it to promote independent learning and to achieve the learning targets specified as part of the reform (CDC, 2001, p.83). Subsequent to the introduction of project learning, a number of articles identified the theoretical foundations and disseminated practical experiences of project learning as a learning strategy (Lee, 2004; Lo, 2004).

Table 1: Classification of Different Kinds of Policy Instruments

\begin{tabular}{|l|l|}
\hline \multicolumn{1}{|c|}{ Hard } & \multicolumn{1}{c|}{ Soft } \\
\hline Confined to legislation and regulations & More adaptable to context \\
\hline Closed method of implementation & Open method of implementation \\
\hline Emphasize planning and result & Emphasize process \\
\hline Policy / centralized control & Local leadership dominant \\
\hline Rigid & Flexible \\
\hline Assuring accountability & Monitoring accountability \\
\hline Compulsory & Voluntary \\
\hline
\end{tabular}

The characteristics of project learning and the roles expected of teachers in this Hong Kong curriculum reform are very similar to the way it has been developed in other countries. Project learning is described by the Curriculum Development Institute (CDI) as a powerful learning and teaching strategy to promote self-directed, self- regulated, and self- reflecting learning. It usually starts with challenging questions or problems, involves students working individually or collaboratively, and aims to connect knowledge, skills, values, and attitudes and to construct knowledge through a variety of learning experiences (CDC, 2001, p.87). Furthermore, as students become more independent in the learning process, 
teachers' roles mainly focus on enabling students to take risks without fear of failure and leading, guiding, supporting and facilitating students' learning (CDC, 2001, pp.87-88).

The key characteristics of project learning have also been highlighted in the international literature. Wray (1998, p.74) proposed that the primary roles of the teacher in project learning are consultant, poser of problems, facilitator, helper, and teacher. Newell (2003, p.5) stressed that project learning changes the roles of the teacher from lecturer and director to resource provider and participant and from expert to advisor or facilitator. The change of the teacher's roles is presented in Table 2, which is based on Katz \& Chard (2000, p.13) and Newell (2003, p.5).

For Hong Kong teachers, the characteristics of project learning represent a significant challenge. Traditionally, Hong Kong has been characterized as having teacher-centered classrooms, and successive reports have highlighted this characterization. As far back as the 1980s a public report noted that lessons were teacher-centered with little use of aids beyond chalk and blackboard, and students were expected to be passive (Llewellyn, 1982, pp. 52-53). This situation did not seem to have changed by the early 1990s, when English lessons emphasized teaching grammar and pronunciation without giving enough opportunity for students to use language meaningfully, and when mathematics lessons in general adopted the teacher demonstration approach without much student engagement (Education Commission, 1993). By mid1990s, just before the introduction of Target Oriented Curriculum (TOC), classrooms were consistently portrayed as teacher-centered, textbook-centered, and test-centered (Morris et al., 1996, p. 4). The TOC, constituting a radical change in the nature of curriculum and teaching, did not have sufficient momentum to bring about innovative teaching. Thus, the prevailing nature of classroom organization usually involved whole-class teaching, and group work and individual work were rare. The predominant form of classroom interaction involved teacher-centered instruction and limited teacher-pupil interaction (Morris et al, 1996, p. 4). Indeed, classroom interaction was still very much controlled by teachers and influenced by textbooks (Mok \& Ko, 2000, p. 192).

Table 2: Contrasting roles of teacher in systematic instruction and project learning

\begin{tabular}{|l|l|l|}
\hline $\begin{array}{l}\text { Developing } \\
\text { skills }\end{array}$ & $\begin{array}{l}\text { Teacher focuses on helping children acquire } \\
\text { skills }\end{array}$ & $\begin{array}{l}\text { Teacher provides opportunities for children to apply } \\
\text { existing or emerging skills }\end{array}$ \\
\hline $\begin{array}{l}\text { Promoting mo- } \\
\text { tivation }\end{array}$ & $\begin{array}{l}\text { Teacher provides extrinsic motivation for stu- } \\
\text { dent achievement }\end{array}$ & $\begin{array}{l}\text { Teacher promotes intrinsic motivation by supporting } \\
\text { projects with student interest and involvement }\end{array}$ \\
\hline $\begin{array}{l}\text { Facilitating } \\
\text { choice }\end{array}$ & $\begin{array}{l}\text { Teacher selects topics, materials, and activities } \\
\text { and sets parameters for student learning }\end{array}$ & $\begin{array}{l}\text { Teacher serves as guidance or consultant for stu- } \\
\text { dent's selection of topic, activities, levels of chal- } \\
\text { lenge, roles, and materials }\end{array}$ \\
\hline $\begin{array}{l}\text { Providing ex- } \\
\text { pertise }\end{array}$ & $\begin{array}{l}\text { Teacher as expert possesses knowledge and } \\
\text { experience that addresses student's deficiencies }\end{array}$ & $\begin{array}{l}\text { Teacher capitalizes on student's proficiencies and } \\
\text { knowledge relating to the project }\end{array}$ \\
\hline $\begin{array}{l}\text { Assuring ac- } \\
\text { countability }\end{array}$ & $\begin{array}{l}\text { Teacher is accountable for student's learning } \\
\text { and achievement }\end{array}$ & $\begin{array}{l}\text { Teacher shares accountability with student for learn- } \\
\text { ing achievement }\end{array}$ \\
\hline $\begin{array}{l}\text { Conducting as- } \\
\text { sessment }\end{array}$ & $\begin{array}{l}\text { Teacher provides the assessment that focuses } \\
\text { on tests, products, or reproduction of informa- } \\
\text { tion }\end{array}$ & $\begin{array}{l}\text { Teacher facilitates the assessment which witnesses } \\
\text { the processes or performances and tangible accom- } \\
\text { plishment. }\end{array}$ \\
\hline
\end{tabular}

Morris et al. (1996, p. 97) observed 172 lessons during the TOC's implementation and found that the four major classroom activities were direct questioning (19.1 percent), questioning (23.3 percent), introduction or feedback (21.2 percent) and supervision (19.8 percent). These four activities occupied 83.4 percent of lesson time. After the TOC's implementation, about 81 percent of primary school principals were satisfied with teachers' traditional approach to teaching but 
only 41.4 percent were satisfied with teachers' use of the activity approach teaching (CART, 1997).

With a culture and history of teacher-centered classrooms in Hong Kong schools, the requirement of project learning for teachers' changing roles is radical. As students are expected to take more active roles in the learning process, teachers' roles are meant to support students to take risks without fear of failure and leading, guiding, supporting, and facilitating students' learning (CDC, 2001, pp. 87-88). Clearly, such a change of teaching approach is very demanding in a society as traditional and pragmatic as Hong Kong (Zhu, 2004, 2005). The apparently successful implementation of project learning in terms of adoption rate by schools, reported to be in some 80 percent of Hong Kong's schools, is even more difficult to understand. The nature of the implementation processes used to facilitate project learning in Hong Kong will be addressed in the following section.

\section{Implementation of project learning: "soft" and "hard" policy instruments}

Education authorities in Hong Kong made concerted efforts to influence schools and teachers to take up project learning. For the purposes of this paper, these efforts are being described in terms of "hard" and "soft" policy instruments, the characteristics of which were described earlier in this paper. We will describe the use of different instruments in the following sections.

\section{"Soft" policy instruments for implementing project learning}

Project learning was launched using "soft" policy instruments. Schools were advised to implement project learning in a flexible way so that it was adaptable to context, and central support units provided additional resources and practical exemplars. "Soft" policy instruments of various kinds were used to support the implementation project learning.

First, the government used extensive curriculum guidelines (CDC, 2001; CDI, 2002) to recommend project learning as a curriculum reform to schools and teachers. This has been a commonly used strategy for implementing curriculum reform in the past (Morris, 1996) as well as in the current curriculum reform (Chan, Kennedy, \& Fok, 2008a). Curriculum guidelines clearly set out expectations and provide exam- ples, therefore setting directions for curriculum planning at the school level. They are not mandatory and schools are encouraged to adapt them to suit local needs. Nevertheless, such guidelines are an important way for the system to make its expectations known.

Second, the government used the Quality Education Fund $(\mathrm{QEF})^{3}$ as another "soft" policy instrument to influence the implementation of project learning. This fund promotes and disseminates good practices distilled from funded projects (QEF, 1998). The approval of QEF grants in the past few years showed that there was a significant emphasis on support for the government's reform agenda. There was no specific emphasis on project learning in the first four rounds. For example, the QEF approved proposals in the first round promoting the quality of teaching and learning, developing all-round education, improving schoolbased management, and conducting educational research. Specific areas included the application of information technology in schools, school-based curriculum, innovative instructional methods, and extracurricular activities (QEF, 1998). In the second round, QEF approved proposals that met four key education objectives: enjoyable learning, effectiveness in communication, commitment, and creativity (QEF, 1999). After the major reform documents were released in 2001, the QEF approved proposals that were in line with curriculum reform. They focused on three designated themes: project learning and curriculum integration, moral and civic education, and reading proficiency (QEF, 2001). The QEF funded some 47 proposals directly related to project learning between 1998 and 2004; of these, 27 were funded in 2001-2002 (QEF, 2004). The reform agenda clearly influenced QEF priorities.

In addition to supporting proposals related to project learning, the QEF launched the Outstanding School Awards (OSA) scheme, which was conceived and developed as an ongoing quality school improvement program. This scheme aimed to recognize and encourage schools with excellent practices and performance, to promote and disseminate schools' excellent education practices, and to cultivate a quality culture within the school sector to strive for excellence according to each school's unique conditions (Quality Education Fund, 2002, p. 1).

The promotion of project learning was one of the key items in this OSA scheme. Among successful 
schools, the implementation of project learning was mentioned throughout the teaching and learning section in the report (QEF, 2002, p. 27, 32, 33, 81). Project learning was mentioned in relation to good classroom practices, such as adjusting to students' different needs (Lee et al., 2004, p.15); developing students' knowledge, higher-order thinking, creativity, selflearning skills, and positive learning attitudes (Lee et al., 2004, p. 20); and promoting effective classroom teaching and learning (Lee et al., 2004, p. 23).

Third, project learning was promoted through the "seed project scheme." In line with the curriculum reform, the CDI initiated a series of collaborative research and developmental projects (seed projects) in schools starting September 2001. These projects were geared towards promoting the learning capabilities of students in order to achieve the aims of the school curriculum. One of the key emphases for 2001-2005 was project learning, and two seed projects were launched as a means of promoting it. (Chan, 2004). The first seed project was called "Developing web-based tools for supporting project learning," supported by the School-Based Curriculum Development (Secondary) and Language Support Section of CDI from September 2001 to September 2002. Thirteen primary and junior secondary schools joined the project (CDI, 2004a). The end product of this project was a Web-based project learning tool to facilitate students' self-learning (EC, 2002, p. 9). The second seed project, "Developing a school-based curriculum for promoting project learning," was supported by the Personal, Social, \& Humanities Education Section and the School-Based Curriculum Development (Secondary) and Language Support Section. Twenty-three junior secondary schools joined the project to develop school-based project learning (CDI, 2004b). A project learning manual was published and four project learning examples were uploaded on a web site as a reference guide for teachers and students (CDI, 2004b).

Fourth, CDI supplied numerous project learning exemplars to schools and teachers. Two sets of these in particular were popular among teachers. Furthermore, one set samples was uploaded to the CDI official website. The content of this website included the guiding steps that involved stages of project learning, curriculum modes, tools for project learning, and four exemplars: "Understanding Wong Tai Sin"; "Interdisciplinary Project Learning Scheme"; "Healthy Super Kids"; and "Understanding Our Food". These four exemplars provided not only descriptions of project objectives, curriculum design, curriculum implementation, assessment, and reflection results, but also examples of actual designs like worksheets, assessment forms, and evaluation questionnaires. These were helpful resources for schools and teachers when they started implementing the project learning approach.

Another set of samples was offered by the CDI's Gifted Education Section. This set included teaching training packages for school-based gifted programs. The training packages had six items, one of which was project learning. The project learning package was designed for Primary 4 to Primary 5 gifted students in interdisciplinary studies and contained three learning packages (Gift Education Section, 2002).

The above examples and illustrations demonstrate central support for project learning through using "soft" policy instruments. Curriculum documents recommended and encouraged schools and teachers to adopt project learning as learning and teaching strategy. The QEF supported project learning proposals and its Outstanding School Awards encouraged and rewarded the implementation of project learning. Seed projects and exemplars also facilitated project learning without strong guidance or firm control. As a whole, the government reform agenda emphasized the formation of partnership or collaboration among schools and society instead of adopting a top-down implementation approach (CDC, 2001, p.4).

Even though these various "soft" policy instruments were voluntary in nature, they nurtured an atmosphere of competitions within the education system. The comparisons between schools and between teachers by the number of awards and recognitions given by the QEF, and the use of exemplars to be set as models for other schools exerted tremendous pressures on schools that did not have any project learning initiatives. To a certain extent, "soft" policy instruments were given a hard edge through processes that has nurtured this competitive atmosphere in a very public way.

\section{"Hard" policy instruments for implementing project} learning

Besides using "soft" policy instruments to implement project learning as a curriculum reform, the government also utilized "hard" policy instrument measures. 
These measures included the implementation of quality assurance inspection (QAI), school self-evaluation (SSE), and external school review (ESR), which were further consolidated under the umbrella of School Development and Accountability (SDA) ${ }^{4}$. They provided another set of processes that affected schools and influenced the nature of project learning implementation.

QAI was fully implemented from 2001-2002 as a hard measure to monitor school performance, and it has exerted a great deal of pressure on schools and teachers. QAI annual reports show the items on which the EMB focused. Before 2001, project learning was not the focus of inspection, and therefore the QAI annual report in 2001-2002 did not have a specific section evaluating the implementation of project learning. After the 2001 education reform that included project learning as one of four key tasks, the QAI annual reports included reference to school performance in the promotion of project learning (e.g. QAD, 2003a; QAD, 2004a). An example is worth quoting:

While most schools had experience in giving project assignments in one or a few subjects before the launch of the CR (curriculum reform), the infusion of project learning in the learning process was at its elementary stage of development. A cross-subject approach to project learning was adopted by about half of the schools inspected to provide opportunities for teamwork and development of students' collaboration skills. It is still important for teachers to play an instructional role in project learning. Students should be guided through the enquiry process so that they could analyse, interpret data and reflect on the learning process. These would help enhance students' generic skills including problem solving skills, selfmanagement skills and self-reflection skills (QAD, 2003a, p.8).

In the QAI Annual Report for 2003-2004, there was a similar paragraph referring to the implementation of project learning in schools (QAD, 2004a, pp. 46-47). Moreover, this report added a section encouraging improvement:

Schools could pay greater attention to the strategic planning, monitoring, and review of the implementation plan. Schools should also develop and refine the skills of teachers in conducting project learning for enhancing student learning. As most students appeared to be relatively weak in problem-solving skills and creative thinking skills, improvement was necessary in these areas (QAD, 2004a, p.48).

In addition to the QAI annual reports, QAI reports for individual schools also referred to project learning as one of the focused items after the 2001 education reform. For example, one inspection report (QAD, $2004 b$, p. 7) praised a secondary school for its learning and teaching strategies with an emphasis on project learning:

The school had set proper priorities and adopted appropriate strategies for the implementation of the four key tasks of the curriculum reform. . . . Individual subject departments engaged actively in cross-curricular collaboration in promoting project learning and some others implemented curriculum innovations, both leading to quality learning outcomes.

Individual school inspection reports were posted on the EMB website for public reference, although not all were complimentary. In this way, good schools were openly praised and so-called poor schools were criticized.

The practice of QAI, systematic internal School Self-evaluation (SSE), and External School Review (ESR) were used as hard instruments to target the quality of education starting in the 2003-2004 academic year (Law, 2003). SSE was assumed to be a whole-school approach activity, the purpose of which was to bring about coherence and strengthen collaboration, communication, and ownership among members of the school community. It included three crucial stages: school development planning, implementation of self-evaluation, and review and follow-up (QAD, 2003b). Within this self-evaluation process, schools highlight the use of performance indicators and success criteria, data management, evaluation tools, school self-assessment, and reporting. ESR was first piloted in 2003-2004 and was regarded as a validation and strengthening of SSE to enhance school development and accountability.

In official terms, these ESR and SSE efforts provided a solid foundation for further improvement of learning and teaching in the classroom (Wardlaw, 2004). In addition, these efforts by schools were not seen as new requirements because they were first implemented after school-based management (SBM) was 
adopted in 2000. The SSE was regarded as an internal quality assurance process and a core element after SBM was promulgated in 1991 (Lee, 2003). Schools were requested to upload these evaluation results onto their own homepage, instead of sending them to EMB.

The initiation of project learning, as well as other curriculum policies, were perceived by the government officials as using "soft" instruments for implementation. Schools and teachers, however, associated all these curriculum policies with "hard" policies and perceived all measures as "hard" policy instruments in the process. All recommendations and suggestions in curriculum guides (CDC, 2001) were becoming rules that were seen as necessary by schools.

When we examine both "hard" and "soft" policy instruments, it is not difficult to understand how they have exerted pressure on schools and teachers. The nature of this pressure and its extent are subject to the perceptions of individual stakeholders. The effects on teachers and the way it was perceived by policymakers will be discussed in the following section.

\section{Discussion}

Kennedy (2005, p. 128) advocated that policymakers need to understand more about teachers:

Policymakers need to understand that different policy actors are likely to construct different meanings for single policies. These differences can affect policy implementation in any number of ways. While governments have responsibility for agenda setting, policy agendas cannot be divorced from the contexts in which policies are to be implemented. There needs to be an appreciation of the interaction between policy agendas and their implementation and the theoretical frameworks that drive both the agenda and its implementation contexts.

This understanding may appear both obvious and simple; however, Hong Kong's education policymakers did not easily grasp the concept. Policymakers claimed that hard policy instruments, including QAI, SSE, and ESR, were simple and routine. For example, QAI aimed to provide participating schools with an external view on their strengths and areas for improvement. Because schools were inspected on a voluntary basis between 1997 and 2000 (Tse, 2005, p. 111), compulsory external monitoring was a very new feature for many schools. Teachers' perceptions of these measures clearly showed that they did not see them as simple. From their perspective, these measures often hindered the school's routine tasks. Chiu (2004) has referred to the differing perceptions held by teachers:

1. Frontline teachers had not participated in forming these measures and the use of quality assurance reports and external school review reports were unclear to schools and teachers.

2. Data uploaded on the school Web site drew the attention of non-professionals and parents, which forced teachers to respond to this external pressure by working as hard as possible.

3. School closures as a result of declining school populations meant that adverse publicity about any school had to be avoided at all costs.

The pressure that QAI and ESR exerted on teachers and schools can be demonstrated by the results of post-inspection questionnaires on QAI full inspection and ESR. Some 41 percent of teachers felt that full inspections interfered with their daily work and 61 percent felt that inspections placed them under pressure (QAD, 2003a, pp. 46-48). Similar results were reported in the following year (QAD, 2004a, pp. A3536 ) and they applied equally to ESR (QAD, 2004a, pp. A37-38). Poon (2005) has highlighted some of the problems faced by teachers:

1. Preparation of a school self-assessment (SSA) report containing more than 100 pages.

2. Some ESR teams were presented with as many as 72 items of recently prepared documentation, including detailed minutes of the array of meetings in schools.

3. Some schools spent an inordinate amount of time rehearsing and coaching for the ESR.

Government officials recognized the pressures that were being exerted on teachers, and this was reflected in the continuous modification of the SSE and ESR schedules. (Law, 2003, Wardlaw, 2004, Poon, 2005). Wardlaw (2004), though stressing the success of SSE and ESR pilots, acknowledged that there was considerable disquiet and concern about some elements of the framework and the SDA's implementation processes. The workload for preparing ESR and SSE and the requirement of uploading the ESR reports to the web were two of the most contentious issues. 
The EMB determined to take appropriate actions to address some of the concerns. To avoid possible misinterpretation and misuse of data, EMB decided that only the key stakeholders in the school need to be informed of the school performance and that the SSE report and ESR reports would not be published on the schools' websites. Poon (2005) listed the modifications of implementation requirements that responded to the teachers' grievances:

1. School self-assessment (SSA) reports should be precise and succinct, focusing on the key issues and improvement measures over the next three years, and should not exceed 20 pages.

2. To avoid heavy workload, ESR teams will examine the SSA report, KPM, and the stakeholder survey findings only. If necessary, the team may refer to other existing documents routinely available in schools, e.g. school development plan, annual report, and curriculum handbook.

3. The ESR reports should not be uploaded for the first cycle.

When the measures meant to ease pressure of quality assurance were finally announced, 300 teachers and principals applauded the amended measures. Lam Seung Wan, chairman of Aided Primary School Principals, agreed that not publishing SSE and ESR results on the internet was beneficial and did not harm anybody. Chu Fu-yau, chairman of the Hong Kong Subsidised Secondary Schools Council, supported the changes and believed that they could reduce unnecessary pressure on school teachers (Mingpao, 16 July 2005).

Project learning, though a minor item within the entire education reform agenda, assumed significance for both teachers and policymakers. The issue seems to be that teachers and policymakers viewed the implementation processes in different ways. Policy makers did not sufficiently understand teachers' perceptions. The "soft" policy instruments used to facilitate the implementation of project learning were designed to be supportive of teachers: curriculum documents, QEF support, the seed project funding, and school practice exemplars were measures designed to make teachers' work easier. Harder measures like QAI, SSE, and ESR were seen by policymakers to offer comments to schools as a "critical friend" who provided rigorous but focused comments on where the school needed to do better and suggestions for how to improve. The evaluation was part of an ongoing process of selfreflection and self-improvement (Poon, 2005). From the officials' views, both "soft" and "hard" measures were simply logical applications of funds and processes to ensure the government's reform objectives.

At the school level, however, teachers' perceptions were quite different. They felt the pressure exerted on them by QAI, SSE, and ESR so that the term "hard" policy is quite appropriate. Yet, the "soft" policy instruments, such as QEF encouragement, exemplars from other schools, seed project funding, and the sharing and provision of curriculum resources, were not as soft as the government officials perceived. These "soft" instruments encouraged competitions for funding and performances among schools. Within the context of a declining school population and the government's right to close schools confirmed in the courts (e.g. Kin Tak Village School, SingPao, 2004), the perceptions on "soft" and "hard" policy instruments were different. Teachers perceived that these were used as evidence to take legitimate action against schools. At the same time there were other system-level events that led teachers to lose confidence in the government. These included the introduction of the school-based management ordinance, and the implementation of the benchmark policy on Putonghua and English that all teachers of these subjects had to pass an external test in order to continue their subject teaching in schools. These initiatives created even more burdens and pressures for teachers who not unnaturally assumed that even a small item like project learning would have a significant effect on their schools. Thus it was the push-pull effect of both "hard" and "soft" policy instruments that most likely accounts for the high level of implementation of project learning. Policymakers used different policy instruments in a logical and avowedly supportive way to secure government objectives; teachers, on the other hand, saw these instruments as threatening and coercive but complied with the directions of reform policy to avoid any negative consequences.

\section{Conclusion}

Teachers' perceptions of "soft" and "hard" policy instruments exerted twin pressures on schools and teachers. Though government officials reiterated the target of QAI, SSE, and ESR as an indication of im- 
provement in school teaching and learning, school principals and teachers still perceived that the policy was a kind of evaluation that would be used for determining the fate of schools (Wong, 2005). Though government officials supported project learning as an innovative approach to student learning, school teachers treated it as an instrument and evidence for QAI, SSE, and ESR. Thus, they felt they had to take it up as if it were a compulsory requirement since it was one of the foci of these measures.

The differing perceptions between government officials and teachers in terms of the policy instruments used to implement project learning are but one example of issues that have arisen in Hong Kong's wideranging curriculum reform. The pressure teachers faced as a result of the reform agenda prompted a protest march organized by the Professional Teachers' Union and triggered by offensive remarks made by the Permanent Secretary for Education, Fanny Law, on January 22, 2006 (SingTao Daily News, 2006). When reporting on the review of teacher workload in August 2006, Lina Hau Yee Yan said, "The work might be perceived as optional by EMB. But when the message reached teachers, it was interpreted as compulsory. A soft indicator has changed to a hard one" (MingPao, 2006).

Finally, the significance of understanding policy making and implementation should be noted (Kennedy, 2005, p. 128):

It is important to understand that policymaking is not a scientific endeavor. It depends on individuals for its success and often these individuals maybe at some distance from the original design of the policy. Policymaking is thus closer to an art than a science and it is firmly embedded in social and political contexts. Understanding and appreciating those complexities is an important first step in recognizing that successful policymaking requires knowledge of both the substantive issues associated with the policy and also the implementation realities on which the policy depends for its success.

Policy objectives can be achieved using "hard" policy instruments or a blend of "hard" and "soft" policy instruments, as was the case in the study reported here. Yet the question raised by this study is whether the ends always justify the means. Indeed, both school policymakers and teachers made curriculum decisions according to their perceptions of policy (Fok, Kennedy, \& Chan, 2008; Chan, Kennedy, \& Fok, 2008b). The pressures faced by Hong Kong teachers have been shown to be very real, even though there was a high level of compliance to avoid poor evaluation results. Compliance, however, should not be mistaken for commitment, as was clearly demonstrated when the system reached a boiling point with the teacher demonstration in early 2006. The subsequent transfer of the Permanent Secretary for Education was perhaps a sign that the system itself had come to recognize the limitations of compliance as an implementation process.

An important contribution that an understanding of "soft" and "hard" policy instruments can make is that they allow an assessment to be made of the likely impact on teachers. In the past, too much emphasis has been placed on the qualities of teachers-or lack of them-as implementers. Perhaps it is time for that emphasis to be placed on policymakers and their ability to select the right policy instrument for the task. Policymakers need to take into consideration the professionalism of teachers and the social and political contexts that regulate schools and schooling. Failure to do so leads to the kind of results reported hereresults that can be attributed to poor policy decisionmaking rather than poor teachers. Focusing on the selection of the most appropriate policy instruments has the potential to make policy-makers accountable. Policy instruments, therefore, deserve much more attention in the education literature than they have currently received. This study has been one step in that direction.

\section{References}

Abbott, K. \& Snidal, D. (2000). Hard and soft law in international governance. International Organization, 54(3), 421-456.

Ahonen, P. (2001). Soft governance, agile Union? Analysis of the extensions of Open Coordination. Paper presented at the $9^{\text {th }}$ NISPAcee Conference, Riga, Latvia, 10-12 May. Retrieved 1 May 2008, from:

http://unpanl.un.org/intradoc/groups/public/docu ments/NISPAcee/UNPAN007710.pdf 
Begg, I. (2004). Hard and soft economic policy coordination under EMU: problems, paradoxes and prospects (Center for European Studies Working Paper Series \#103). Cambridge, MA.: Harvard.

Begg, I., Hodson, D., \& Maher, I. (2003). Economic policy coordination in the European Union. National Institute Economic Review, 183, 66-77.

Chan, K. K. (2004). Collaborative Research and Development ("Seed") Projects for 2004-2005 (Education \& Manpower Bureau Circular Memorandum No.71/2004) (EMB(CD)/ADM/150/1/

129(1)). Retrieved from:

http://cd.emb.gov.hk/seed/circular/CM71_2004_E. pdf.

Chan, K. S. J., Kennedy, K. J., \& Fok, P. K. (2008a). "Hard" and "soft" policy for the school curriculum: The changing role of teachers in the learning to learn' reform. In J. Lee, L. Lo \& L. P. Shiu (Eds.). Developing teachers and developing schools in changing contexts (pp. 135-152). Hong Kong: Chinese University Press.

Chan, J. K. S., Kennedy, K. J., \& Fok, P. K. (2008b). Teacher's perspective on "soft" and "hard" curriculum policy (in Chinese). In J. K. W. Chu, S. P. Cheung, E. L. Y. Lai, K. H. Fung (Eds.), The proceedings of the $10^{\text {th }}$ Curriculum Studies Academic Conference for Mainland, Taiwan and Hong Kong: Curriculum decisionmaking (pp.233-244). Hong Kong: Faculty of Education, The Chinese University of Hong Kong.

Chiu, C. S. (2004). Revisiting school self evaluation and external school review. PTU Bulletin, 491. (in Chinese). 24 Nov 2005 retrieved from:

http://www.hkptu.org/ptu/director/pubdep/ptunew s/491/mirco.htm

Chrispeels, J. (1997). Educational policy implementation in a shifting political climate: the California experience. American Educational Research Journal, 34(3), 453-481.

Cini, M. (2001). The soft law approach: Commission rule-making in the EU's state aid regime. Journal of European Public Policy, 8(2), 192-207.

Contextual Analysis Research Team [CART]. (1997). Contextual analysis for programme development. Hong Kong: Hong Kong Institute of Education.

Curriculum Development Council [CDC]. (2001). Learning to learn: The way forward in curriculum. Hong Kong: The Printing Department.
Curriculum Development Institute [CDI]. (2002). Project learning and inquiry learning in Personal, Social, and Humanities Education. 25 Nov 2005 retrieved from:

http://www.pshe.inquirylearning.edu.hk/ main.asp.

Curriculum Development Institute [CDI]. (2004a). Collaborative research and development ("Seed") projects. 24 Nov 2005 retrieved from: http://cd.emb.gov.hk/seed/chi/index.htm

Curriculum Development Institute [CDI]. (2004b). Seed project to promote project learning. $24 \mathrm{Nov}$ 2005 retrieved from:

http://cd.emb.gov.hk/seed/chi/

Ed Doern, G. B., \& Phidd, R. W. (1992) Canadian public politics: ideas, structure, process ( $2^{\text {nd }} \mathrm{Ed}$.). Toronto: Nelson Canada.

Education and Manpower Bureau [EMB]. (2004). Report of survey on the school curriculum reform and implementation of key learning area curricula in schools 2003. Hong Kong: Education and Manpower Bureau.

Education Commission [EC]. (1993). Quality in school education: Report of the working group on educational standards. Hong Kong: Government Printer.

Education Commission [EC]. (2002). Progress report on the education reform (1). Hong Kong: Education Commission.

Education Commission [EC]. (2004). Progress report on the education reform (3). Hong Kong: Education Commission.

Fok, P. K., Kennedy, K. J., \& Chan, J. K. S. (2008). The foundation for school curriculum decisionmaking: Understanding for curriculum policy makers (in Chinese). In J. K. W. Chu, S. P. Cheung, E. L. Y. Lai, K. H. Fung (Eds.), The proceedings of the $10^{\text {th }}$ Curriculum Studies Academic Conference for Mainland, Taiwan and Hong Kong: Curriculum decisionmaking (pp.493-508). Hong Kong: Faculty of Education, The Chinese University of Hong Kong.

Gifted Education Section, CDI. (2002). Teacher training package for school-based gifted programme on project learning. 24 Nov 2005 retrieved from: http://www.emb.gov.hk/index.aspx?langno=1 \&nod $\mathrm{eID}=3613$ 
Hannaway, J., \& Woodroffe, N. (2003). Policy instruments in education. Review of Research in Education, 27, 1-25.

Hertin, J., Berkhout, F., Tyteca, D., \& Wehrmeyer, W. (2003). Are soft policy instruments effective? Establishing the link between environmental management systems and the environmental performance of companies. Berlin Conference on the Human Dimension of Global Environmental Change, 1-6 December 2003.

Hong Kong Special Administrative Region [HKSAR]. (2004). Hong Kong 2004. Hong Kong: HKSAR.

Howlett, M. \& Ramesh, M. (1995) Studying public policy: policy cycles and policy subsystem (New York, Oxford University Press).

Katz, L. G., \& Chard, S. C. (2000). Engaging children's minds: The project approach $\left(2^{\text {nd }}\right.$ ed.). Stamford, CT.: Ablex Publishing Corporation.

Kennedy, K. J. (2005). Changing schools for changing times: New directions for the school curriculum in Hong Kong. Hong Kong: The Chinese University Press.

Kennedy, K. J., Chan, K. S. J. \& Fok, P. K. (2006). Theorizing curriculum policy implementation: the dimensions of "soft" policy and their application to Hong Kong's reform agenda. Paper prepared for The Asia-Pacific Educational Research Association Conference, Hong Kong, 28-30 November, 2006.

Koulaimah-Gabriel, A., \& Oomen, A. (1997). Improving coherence: challenges for European development cooperation (Policy management brief no. 9). Maastricht: ECDPM.

Law, F. (9 May 2003). Enhancing School development and accountability through School Self-evaluation and external School Review. 15 Nov 2005 retrieved from:

http://www.emb.gov.hk/FileManager/EN/Content_4 861/sch_evaluatione.pdf

Lee, J. C. K. (2004). Project learning: in search of theoretical foundation for curriculum reform (in Chinese). Hong Kong Teachers' Centre Journal, 2, 93104.
Lee, J. C. K. et al. (2004). Report on OSA highlight studies: Domain two - teaching and learning. Hong Kong: QEF; Centre for University and School Partnership, Faculty of Education, The Chinese University of Hong Kong; Hong Kong Institute of Educational Research, the Chinese University of Hong Kong.

Lee, Y. F. (12 June 2003). Enhancing school development and accountability through school selfevaluation and external school review. (Education and Manpower Bureau circular no. 23/2003) (Ref: EMB(SBM) TASKS/20 Pt.2). Hong Kong: EMB.

Llewellyn, J., Hancock, G., Kirst, M., \& Roeloffs, K. (1982). A perspective on education in Hong Kong: Report by a visiting panel. Hong Kong: Government Printer.

Lo, S. Y. (2004). Implementing social project learning in the Key Learning Area of Personal, Social and Humanities. Hong Kong Teachers' Centre Journal, 2, 105-108.

McDonnell, L. M., \& Elmore, R. F. (1987). Getting the job done: alternative policy instruments. Educational Evaluation and Policy Analysis, 9(2), 133152.

Mingpao (16 July 2005). External school report not open to public.

MingPao (2006, 24 Aug). Reporting of reviewing teachers' pressure: pressure partly comes from education reform.

Mok, I. A. C., \& Ko, P. Y. (2000). Beyond labels teacher-centred and pupil-centred activities, in: B. Adamson, T. Kwan, \& K. K. Chan (Eds.) Changing the curriculum: the impact of reform on primary schooling in Hong Kong (pp.175-193). Hong Kong: Hong Kong University Press.

Morris, P. (1996). The Hong Kong school curriculum: Development, issues and politics. Hong Kong: Hong Kong University Press.

Morris, P. et al. (1996). Target oriented curriculum evaluation project: Interim report. Hong Kong: INSTEP, Faculty of Education, University of Hong Kong.

Newell, R. J. (2003). Passion for learning: how projectbased learning meets the needs of $21^{\text {st }}$ century students. Lanham: the Scarecrow Press, Inc. 
Organisation for Economic Co-operation and Development [OECD]. (2004). Communicating environmentally sustainable transport. 25 Feb 2006 retrieved from:

http://usa2.ebooks.com/ebooks/book_display.asp?II $\mathrm{D}=236160$

Peters, B. G.. (2000). Policy instruments and public management: bridging the gaps, Journal of Public Administration Research and Theory, 10(1), 35-47.

Poon, A. C. S. (2005). School Self-evaluation and External School Review modification of implementation requirements. EMB(QA/INS/ESR/1. 29 July 2005.

Quality Assurance Division (QAD). (2002). Inspection annual report 2001-2002. Hong Kong: Quality Assurance Inspection, Education and Manpower Bureau.

Quality Assurance Division (QAD). (2003a). Inspection annual report 2002-2003. Hong Kong: Quality Assurance Inspection, Education and Manpower Bureau.

Quality Assurance Division [QAD]. (2003b). School self evaluation. 24 Nov 2005 retrieved from http://www.emb.gov.hk/FileManager/EN/Content_1 412/e_foreword.pdf

Quality Assurance Division [QAD]. (2004b) External school review report: Ho Fung College (sponsored by Sik Sik Yuen) Hong Kong: Education and Manpower Bureau.

Quality Assurance Division. (2004a). Inspection annual report 2003-2004. Hong Kong: Quality Assurance Inspection, Education and Manpower Bureau.

Quality Education Fund (QEF). (1998). QEF general information (13 July 1998). 24 Nov 2005 retrieved from http://qef.org.hk/eng/main.htm?plan/plan02.htm.

Quality Education Fund (QEF). (1999). QEF general information (10 May 1999). 24 Nov 2005 retrieved from: http://qef.org.hk/eng/main.htm?plan/plan02.htm.

Quality Education Fund (QEF). (2001). QEF general information (Sept 2001). 24 Nov 2005 retrieved from http://qef.org.hk/eng/main.htm?plan/plan02.htm.

Quality Education Fund (QEF). (2002). Report on Outstanding School Awards. Hong Kong: QEF.
Quality Education Fund (QEF). (2004). Effective learning: project learning. 13 Feburary 2008 retrieved from:

http://qcrc.qef.org.hk/qef/result.phtml?nature_id=6 \&subnature_id=63\&subcat_id=6303\&app_no=1 \&benef $=-1$ \&mode=browse

Ritchie, E. (2003). Modes of regulation in the Common Fisheries policy: A movable feast. Paper presented at the European Union Studies Association Biennial Conference, March 27-29, 2003. 15 Jan 2009 retrieved from http://aei.pitt.edu/2913/

SingPao (2004, 10 Aug). School closure caused by resources, schooling should rely on vision (in Chinese).

SingTao Daily News (23 Jan 2006). Ten thousand people protest march cried for heavy workloads of education reform.

Stewart, J. (1993). Rational choice theory, public policy and the liberal state. Policy Sciences, 26, 317330.

Stone, D. (1997). Policy paradox: The art of political decision making. New York: W.W. Norton.

Torenvlied, R. \& Akkerman, A. (2004). Theory of "soft" policy implementation in multilevel systems with an application to social partnership in the Netherlands. Acta Politica, 39, 31-58.

Tse, T. K. C. (2005). Quality education in Hong Kong: the anomalies of management and marketization. In L. S. Ho, P. Morris, \& Y. P. Chung (Eds.) Education reform and the quest for excellence: the Hong Kong story (pp.99-124). Hong Kong: Hong Kong University Press.

Vedung, E. (1998). Policy instruments: typologies and theories. In M. Bemelmans-Videc, R. C. Rist \& E. Vedung (Eds.), Carrots, sticks \& sermons : policy instruments and their evaluation. New Jersey: New Brunswick.

Wardlaw, C. (6 June 2004). Enhancing School Development and Accountability through Self-evaluation and External Review: Modification of Implementation Requirements. Ref. no.: EMB (QA/INS)/ESR/1. Hong Kong: EMB.

Wong, K. L. (5 July 2005). Discussing school self evaluation (in Chinese). Tai Kung Pao. 24 Nov 2005 retrieved from:

http://www.takungpao.com/news/2005-7-5/JX423180.htm 
Wray, D. (1998). Inquiry in the classroom: creating it, encouraging it, enjoying it. Toronto: Pippin Publishing.

Zhu, J. Y. (2004). Inquiring into the relationship between project learning and teachers' teaching: From the views of teachers' difficulties. Paper presented at the $6^{\text {th }}$ Curriculum Studies Academic Conference, 22-25 July, Taipei Normal College, Taiwan.

Zhu, J. Y. (2005). Impact of teacher-change agency partnerships on teacher learning : learning through project learning (in Chinese). Unpublished doctoral thesis, The Chinese University of Hong Kong, Hong Kong.

${ }^{1}$ The research reported here was funded as a Competitive Earmarked Research Grant [HKIEd8403/05H] by the Research Grants Council of Hong Kong. The views expressed here are those of the authors and not the funding body.

${ }^{2}$ These instruments are being referred to as soft policy instruments because they are only guidelines or instructions instead of having legal binding force.

${ }^{3}$ Quality Education Fund (QEF), with an amount of $\$ 5$ billion, was set up in 1998 to fund worthwhile educational initiatives. After the government proposed educational reform in 1999 and curriculum reform in 2001, this fund became a major financial source to support initiatives related to educational and curriculum reform.

${ }^{4}$ To enhance the quality of education in kindergarten, primary and secondary sectors, EMB proposed and development various measures to review or inspect school performance. The Quality Assurance Inspection in a whole school approach as full inspection or focus inspection in key issues and priorities to support the education reform that was implemented since academic year 2001-2002. In additional to QAI, schools have to conduct the internal School Self Evaluation and to pass External School Review that is under the School Development and Accountability Framework aiming to enhancing the development and accountability of schools.

IJEPL is a joint publication of the Association for Supervision and Curriculum Development, the Faculty of Education at Simon Fraser University, and the College of Education and Human Development at George Mason University. By virtue of their appearance in this open access journal, articles are free to use, with proper attribution, in educational and other non-commercial settings 90 days after initial publication. Copyright for articles published in IJEPL is retained by the authors. More information is available on the IJEPL Web site: http://www.ijepl.org 